\title{
Cross-Reaction between Gliadin and Different Food and Tissue Antigens
}

\author{
Aristo Vojdani $^{12^{* *}}$, Igal Tarash ${ }^{1}$ \\ ${ }^{1}$ Immunosciences Lab., Inc., Los Angeles, USA; ${ }^{2}$ Cyrex Labs, LLC., Phoenix, USA. \\ Email: *drari@msn.com
}

Received August 22 $2^{\text {nd }}, 2012$; revised December $6^{\text {th }}, 2012$; accepted December $13^{\text {th }}, 2012$

\begin{abstract}
A subgroup of coeliac disease patients continues to experience symptoms even on a gluten-free diet (GFD). We attempted to determine whether these symptoms could be due to either cross-contamination with gluten-containing foods or cross-reactivity between $\alpha$-gliadin and non-gluten foods consumed on a GFD. We measured the reactivity of affinity-purified polyclonal and monoclonal $\alpha$-gliadin 33-mer peptide antibodies against gliadin and additional food antigens commonly consumed by patients on a GFD using ELISA and dot-blot. We also examined the immune reactivity of these antibodies with various tissue antigens. We observed significant immune reactivity when these antibodies were applied to cow's milk, milk chocolate, milk butyrophilin, whey protein, casein, yeast, oats, corn, millet, instant coffee and rice. To investigate whether there was cross-reactivity between $\alpha$-gliadin antibody and different tissue antigens, we measured the degree to which this antibody bound to these antigens. The most significant binding occurred with asialoganglioside, hepatocyte, glutamic acid decarboxylase 65, adrenal 21-hydroxylase, and various neural antigens. The specificity of anti- $\alpha$-gliadin binding to different food and tissue antigens was demonstrated by absorption and inhibition studies. We also observed significant cross-reactivity between $\alpha$-gliadin 33-mer and various food antigens, but some of these reactions were associated with the contamination of non-gluten foods with traces of gluten. The consumption of cross-reactive foods as well as gluten-contaminated foods may be responsible for the continuing symptoms presented by a subgroup of patients with coeliac disease. The lack of response of some CD patients may also be due to antibody cross-reactivity with non-gliadin foods. These should then be treated as gluten-like peptides and should also be excluded from the diet when the GFD seems to fail.
\end{abstract}

Keywords: Cross-Reaction; Gliadin; Food Antigens; Tissue Antigens; Celiac Disease; Gluten-Free Diet

\section{Introduction}

Gluten sensitivity and celiac disease (CD) are gastrointestinal disorders resulting from a breakdown in oral tolerance and a subsequent inappropriate immune response against wheat proteins $[1,2]$. A majority of these patients have specific antibodies directed against tissue transglutaminase, various gliadins, glutenins, gluteomorphins, wheat germ agglutinin protein and peptides [3]. If left untreated, individuals may develop autoimmune injury to the gut, skin, brain, joints, liver, thyroid, bone, reproductive organs and other parts of the body [4].

The commonly recognized therapy for these disorders is a gluten-free diet (GFD). However, the response to a GFD is poor in up to $30 \%$ of patients, and patients may exhibit persistent or recurrent symptoms [5]. In fact, when histological response was assessed in celiac patients after 6 months of following a GFD, complete normalization and reconstruction of villous architecture was

${ }^{*}$ Corresponding author. observed only in $8 \%$ of individuals, while $65 \%$ of these patients were in remission and $27 \%$ did not respond to GFD and had no observable change in their clinical symptoms [6]. The lack of improvement in histopathology and clinical symptomatology in a subgroup of patients on a GFD may be associated with dietary non-adherence or cross-reactive epitopes triggering a state of heightened immunological reactivity in gluten-sensitive individuals [7]. Indeed, celiac peptides that are recognized by sera from patients with active disease share homology with various self-microbial and food antigens [8]. These include Rotavirus major neutralizing protein VP-7, human heat shock protein-60, desmoglein-1 or myotubularin-related protein-2, collagen type VII, tolllike receptor-4, Saccharomyces cerevisiae, and milk proteins $[8,9-13]$. In one study, because patients with $C D$ still had GI symptoms, researchers suspected that cow's milk protein may have been involved. Therefore, they used rectal protein challenge to investigate the inflammatory reaction to gluten and milk proteins in 20 adult 
CD patients and 15 healthy controls. A mucosal inflammatory response similar to that elicited by gluten was observed by cow's milk protein in approximately $50 \%$ of the patients but not in controls. This was determined by measuring neutrophil myeloperoxidase release and nitric oxide production. The researchers concluded that casein was involved in the induction of CD-like symptoms [13].

Some of these cross-reactive antibodies may alter the intestinal barrier integrity, which is the key feature of the early stages of $\mathrm{CD}$ and many autoimmune disorders $[8,14]$. Despite the immense progress in our understanding of the pathogenesis of $C D$ and the well-recognized environmental triggers such as gliadin, little attention has been given to the role that cross-reactive epitopes from various food antigens play in the subgroup of patients with gluten sensitivity/CD whose symptoms do not improve on a GFD.

In this study, we identified antigens and peptides from milk, yeast, millet, corn, rice, oats and tissues that strongly reacted with both affinity-purified as well as monoclonal antibodies produced against $\alpha$-gliadin 33 mer peptide (gliadin). The reactivity between gliadin peptides and various food antigens are pathogenetically relevant becauseif the presence of these cross-reactive substances are left untreated, an individual may develop multiple autoimmune reactivities.

\section{Materials and Methods}

\subsection{Preparation of Food Extracts and Tissue Antigens}

Food products in both raw and processed forms were purchased from large supermarket chains to reflect American purchasing habits and the accessibility of food products. Coffee was purchased from different sources, including supermarkets and coffee houses such as Starbucks, Coffee Bean, and Peet's Coffee in pure roasted bean, instant, latte, and espresso forms. The pure coffee was obtained from Colombia, Turkey, Israel, Brazil, and Hawaii. Peptides from $\alpha$-casein, $\beta$-casein, casomorphin, and milk butyrophilin were synthesized by Biosynthesis, Lewisville, TX. Table 1 shows the foods that were used for the extraction of antigens, as well as various pure tissue antigens, enzymes, and peptides that were purchased from either Sigma Chemicals, Life Sciences, or Biosynthesis. We made sure that the raw purchased foods were not contaminated with gluten-containing grains. We also took extra precautions that the various antigen preparations were not contaminated with gluten during lab work.

Each food item was ground at $4^{\circ} \mathrm{C}$ using a food processor, and extraction buffers and reagents, such as Coco buffer $\left(0.55 \% \mathrm{NaHCO}_{3}, 1 \% \mathrm{NaCl}\right)$ and $70 \%$ ethanol were added [15].

Each food item was then mixed in different solvents and kept on the stirrer for $2 \mathrm{~h}$ at room temperature. After centrifugation at $2000 \mathrm{~g}$ for 15 minutes, the liquid phase from each solvent was removed and dialyzed against $0.01 \mathrm{M}$ PBS using dialysis bags with a cutoff of $6000 \mathrm{Da}$ to ensure that all small molecules were removed. After dialysis, extracted antigens from the above processes were combined, and protein concentrations were measured using a kit provided by Bio-Rad (Hercules, CA).

Table 1. Antigens used for cross-reactivity studies.

\begin{tabular}{ll|ll}
\hline \multicolumn{1}{c|}{ Food antigens } & & & \multicolumn{1}{c}{ Tissue antigens or peptides } \\
\hline Cow's milk & Millet & Parietal cell & Osteocyte \\
$\alpha-+\beta$-casein & Hemp & Intrinsic Factor & Hepatocyte Cytochrome P-450 \\
Casomorphin & Amaranth & Neutrophil cytoplasmic antigen & Insulin \\
Milk butyrophilin & Quinoa & Tropomyosin & Islet cell antigen \\
Whey protein & Tapioca & Thyroglobulin & Glutamic acid decarboxylase 65 \\
Milk chocolate, pure cocoa, dark chocolate & Teff & Thyroid peroxidase & Prostate gland \\
Wheat & Soy & Adrenal 21-hydroxylase & Placenta \\
Oats & Egg & Myocardial peptide & Myelin basic protein \\
Yeast(brewer's, baker's) & Corn & $\alpha$-myosin & Asialoganglioside \\
Coffee(instant, latte, espresso, imported) & Rice & Phospholipid & $\alpha$ - + $\beta$-tubulin \\
Sesame & Potato & Platelet glycoprotein & Cerebellar \\
Buckwheat & & Fibulin & Synapsin \\
Sorghum & & Collagen type IV & \\
\hline
\end{tabular}

Left side shows foods that were used for the extraction of antigens; right side shows various pure tissue antigens, enzymes and peptides from commercial sources. 


\subsection{Preparation of Affinity-Purified $\alpha$-Gliadin 33-Mer Peptide Antibody}

$\alpha$-gliadin 33-mer peptide was synthesized by Biosynthesis Inc. (Lewisville, TX) at a purity of greater than $90 \%$, which was determined by HPLC. The immunization protocol conformed to The Guide for the Care and Use of Laboratory Animals published by the National Institutes of Health, publication no. 85-23, 1985 and was approved by the Institutional Animal Care and Use Committee. Before immunization, 2-mL blood samples from each of two 3-month-old rabbits were used as pre-immunization specimens. The two rabbits were injected every other week with $1 \mathrm{mg}$ of $\alpha$-gliadin 33-mer peptide in complete Freund's adjuvant. Each rabbit received 12 different injections over a 6-month period. Two other rabbits served as non-immunized controls, and they were treated with 12 different injections of saline. Blood was collected from each rabbit at 2, 4, and 6 months after the first injection and was kept at $-20^{\circ} \mathrm{C}$.

Four weeks following the final injection, blood was collected from each rabbit, and immunoglobulins were precipitated and purified by affinity chromatography using protein-A sepharose. CNBr-activated sepharose 4B (SIGMA, St. Louis, MO) was washed with $0.3 \mathrm{M}$ hydrochloric acid and mixed with $10 \mathrm{mg} / \mathrm{mL} \alpha$-gliadin in $0.1 \mathrm{M}$ bicarbonate buffer ( $\mathrm{pH}$ 9.6) per gram of sepharose. The mixture was retained on the stirrer for 60 minutes at room temperature and was alternatively washed in $0.1 \mathrm{M}$ nonacetate/nonborate 3 times and blocked with $3 \%$ bovine serum albumin (BSA). The material was then put into an affinity column (Biorad Laboratories, Hercules, $\mathrm{CA}$ ) and washed extensively with $0.1 \mathrm{M}$ PBS. For purification of antibodies, $5 \mathrm{~mL}$ of immunoglobulins was dialyzed against PBS and then added to the affinity column filled with $\alpha$-gliadin peptide bound to sepharose 4B. After a 1-hour incubation at room temperature, the antibodies were passed through each affinity column, and samples were collected by gravity. The protein content of each effluent was monitored continuously at $280 \mathrm{~nm}$. When the optical density (OD) was read at $280 \mathrm{~nm}$, the wavelength returned to baseline; the respective bound antibodies were then eluted with $0.1 \mathrm{M}$ glycine ( $\mathrm{pH}$ 3.0) into $0.1 \mathrm{M}$ Tris ( $\mathrm{pH} 11.0$ ), thus minimizing exposure of the antibody to acid. The effluent of each column was dialyzed against $0.01 \mathrm{M}$ PBS ( $\mathrm{pH}$ 7.2), concentrated to the original volume, and kept at $-70^{\circ} \mathrm{C}$ until used.

Mouse monoclonal anti- $\alpha$-gliadin 33-mer peptide(G12) antibody was purchased from Biomedal Diagnostic in Spain. The antibody is derived from the hybridoma produced by the fusion of SP2 myeloma cells and splenocytes from a BALB/c mouse immunized with an immunotoxic fraction of gluten recombinant polypeptide. G12 recognizes heptameric gluten-derived immunotoxic pep- tides (QPQLPY). The antibody is unconjugate and therefore offers a great flexibility of detection using a seconddary antibody conjugated with either horseradish peroxidase (HRP) or alkaline phosphatase (AP). It provides high sensibility with low background.

\subsection{Immunoassays}

The IgG antibody levels against different food and tissue antigens in rabbit sera before and after immunization were analyzed by indirect ELISA. Specifically, microtiter plates were coated with $0.1 \mathrm{~mL}$ of either human serum albumin (HSA) in duplicate, which served as controls, or with food extracts, tissue proteins or peptides at a protein concentration of $10 \mu \mathrm{g} / \mathrm{mL}$. Following incubation, washing, and blocking with $2 \% \mathrm{BSA}, 0.1 \mathrm{~mL}$ of rabbit serum diluted to $1: 400$ in serum diluent buffer $(2 \%$ BSA in $0.1 \mathrm{~mL}$; PBS plus $0.01 \%$ Tween 20 ) was added into the quadruplicate wells of the plates. Following incubation, washing, and addition of a second antibody (goat anti-rabbit or goat anti-mouse IgG labeled with alkaline phosphatase) and substrate (para-Nitrophenylphosphate), color development was measured at $405 \mathrm{~nm}$.

Immunoblot analysis of several food and tissue antigens was performed using anti-gliadin 33-mer peptide and a protein blotting nitrocellulose membrane manufactured by Millipore (Bedford, MA). Briefly, the membrane was immersed first in 100\% methanol and then in water for $2 \mathrm{~min}$, followed by equilibration with a buffer containing $25 \mathrm{mM}$ Tris, $120 \mathrm{mM}$ glycine, $\mathrm{pH}$ 8.6. A total of $5 \mu \mathrm{l}$ or $10 \mu \mathrm{g}$ of each protein was added to the membrane and kept at room temperature for $4 \mathrm{~h}$. Blots were blocked for $2 \mathrm{~h}$ in Tris buffer containing 1.5\% BSA and $1.5 \%$ gelatin. After incubation for $1 \mathrm{~h}$ with anti-gliadin, each blot was washed, and then enzyme-labeled goat anti-rabbit or anti-mouse immunoglobulin was added. Visualization of the antibody-antigen reaction was conducted after additional incubation and washing using ECL blot detection reagents (Amersham Life Science) according to the manufacturer's instructions.

\subsection{Inhibition Study for Demonstration of Cross-Reactivity}

A total of $200 \mu$ lof rabbit anti- $\alpha$-gliadin was added to tubes numbered from 1 to 13 . Tube no. 1 received $100 \mu \mathrm{l}$ of $10 \mathrm{mg} / \mathrm{mL}$ HSA. Tubes 2-13 received $100 \mu \mathrm{l}$ of 10 $\mathrm{mg} / \mathrm{mL} \alpha$-gliadin, milk, yeast, $\alpha$ - $+\beta$-casein, coffee bean extract, instant coffee, millet, corn, rice, glutamic acid decarboxylase 65 (GAD-65), cytochrome P450 (hepatocyte), asialoganglioside or collagen type IV. After vortexing, $0.7 \mathrm{~mL}$ of $0.1 \mathrm{M}$ PBS (pH 7.2) was added to each tube and mixed. The tubes were then kept for $3 \mathrm{~h}$ at $37^{\circ} \mathrm{C}$, after which they were kept overnight at $4^{\circ} \mathrm{C}$ and centrifuged at $10,000 \mathrm{~g}$; the supernatant from each tube was 
used in the ELISA testing. The percentage of $\alpha$-gliadin antibody binding to each of the food antigens was measured, and the percent of inhibition was calculated. The inhibition of anti- $\alpha$-gliadin 33 -mer peptide binding to gliadin by different concentrations of food antigens in the liquid phase was used to further demonstrate cross-reaction between different foodantigens and $\alpha$-gliadin. $100 \mu \mathrm{l}$ of serum diluent buffer was then added to all of the wells of a microtiter plate coated with $\alpha$-gliadin. $\alpha$-gliadin, yeast, casein, instant coffee and soy antigens were added to the second row and were titered down the column at half-log dilutions. After $30 \mathrm{~min}$ of incubation, $100 \mu \mathrm{l}$ of rabbit anti- $\alpha$-gliadin 33-mer peptide was added to all wells of the particular columns. Following the addition of the enzyme-labeled anti-rabbit IgG, incubation, and washing, substrate color development was measured at $405 \mathrm{~nm}$. The results were calculated as the percentages of the inhibition of antigen-antibody binding.

\section{Results and Discussion}

Once gluten sensitivity is identified, the treatment of choice for this disorder is a gluten-free diet. This may not be easy to adhere to, as the widespread use of gluten in food preparations and their contamination with trace amounts of gluten make dietary adherence extremely difficult [16]. Furthermore, it has been established that other food antigens cross-react with various wheat anti- gens $[6,8,13,17]$. Because foods contaminated with even trace amounts of gluten and cross-reactive epitopes have the capacity to trigger heightened immunological reactivity in gluten-sensitive individuals, this study was conducted to identify cross-reactivity between $\alpha$-gliadin and non-gluten containing foods that are commonly recommended for patients on a gluten-free diet.

Affinity-purified polyclonal antibodies as well as monoclonal antibodies against $\alpha$-gliadin 33-mer peptide, which is the major peptide involved in celiac disease, were applied to the ELISA plate wells coated with the 24 food and 24 tissue antigens listed in Table 1. The results of anti-gliadin 33-mer peptide binding to different food antigens, expressed as optical density (OD) at $405 \mathrm{~nm}$, are shown in Figures 1 and 2.

The reaction of the affinity-purified rabbit anti- $\alpha$-gliadin 33-mer peptide with gliadin resulted in a very high OD of 2.5. In comparison, this immune reaction expressed by OD against various food antigens was the greatest against $\alpha-+\beta$-casein (1.45), followed by yeast (0.94), casomorphin (0.86), oat cultivar \#2 (0.68), fresh corn $(0.68)$, milk $(0.61)$, millet $(0.51)$, milk chocolate $(0.49)$, instant coffee $(0.46)$, rice $(0.45)$, milk butyrophilin (0.39), and whey protein (0.36), while the immune reactions against oat cultivar \#1, sesame, buckwheat, sorghum, hemp, amaranth, quinoa, tapioca, teff, soy, egg, and potatoes were less than $1 \mathrm{SD}$ above the mean of the

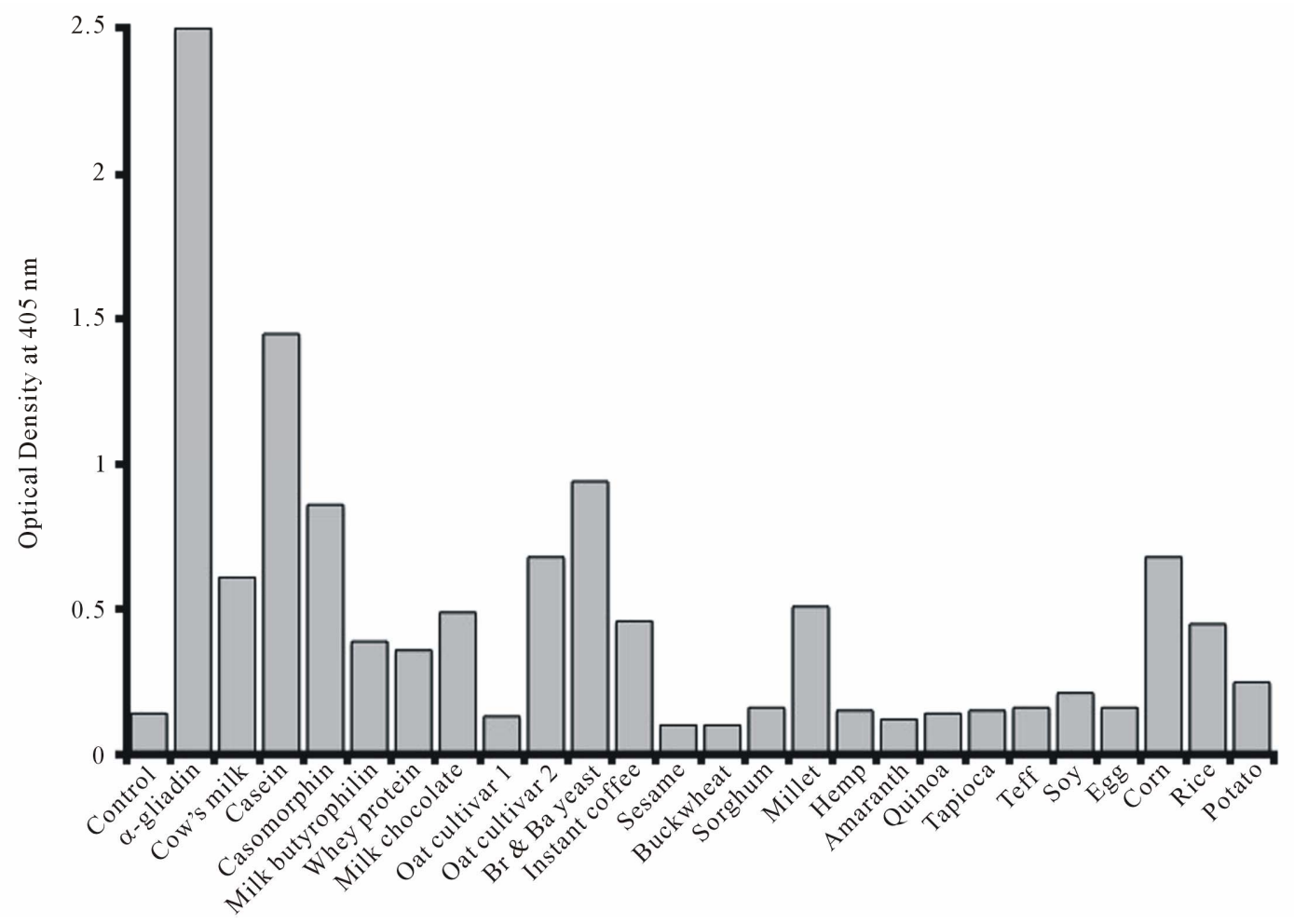

Figure 1. Reaction of affinity-purified $\alpha$-gliadin 33-mer polyclonal antibodies to gliadin and different food antigens. Br yeast $=$ Brewer's yeast; Ba yeast $=$ Baker's yeast . 


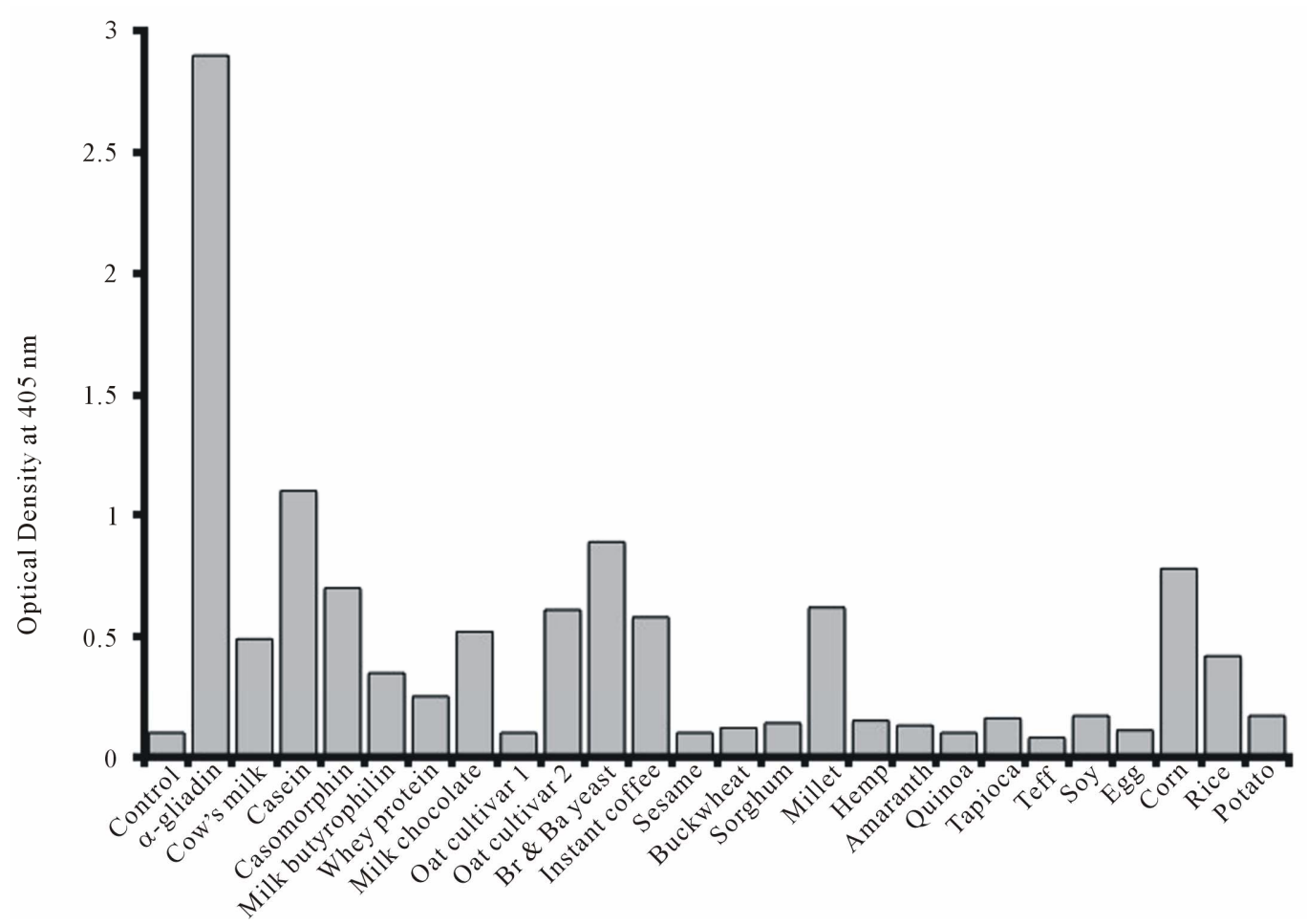

Figure 2. Reaction of $\alpha$-gliadin 33-mer monoclonal antibodies to gliadin and different food antigens. Br yeast $=$ Brewer's yeast; Ba yeast $=$ Baker's yeast.

ELISA background OD (Figure 1). Very similar reactivity was observed when monoclonal anti- $\alpha$-gliadin 33 -mer peptide antibodies were applied to these food antigens (Figure 2). The reaction of these monoclonal antibodies was the greatest against $\alpha-+\beta$-casein, casomorphin, yeast, corn, millet, instant coffee, and oat cultivar \#2, while reactivity for oat cultivar \#1 was negative.

The specificity of these antibodies binding to nongluten-containing foods was confirmed by absorption and ELISA inhibition assays (Figure 3, Table 2). In relation to anti- $\alpha$-gliadin 33 -mer peptide binding to $\alpha$ - + $\beta$-casein, milk, and milk chocolate, it has been shown that there is a high degree of homology orcross-reactivity between bovine $\alpha$ - $+\beta$-casein and the $\alpha$-gliadin 33-mer peptide sequence LQLQPFPQPQLPYUPQPQLPYPQPQLPYPQPQPF [18]. This homology between milk proteins is demonstrated not only by IgA-anti-gliadin antibody immune reactivity with milk proteins [19] but also by IgA reactivity to $\alpha-+\beta$-casein in celiac disease [20] and the induction of local inflammatory reaction after rectal challenge with wheat and milk proteins [13]. The cross-reactivity between gliadin and casein was also confirmed in the present study because anti- $\alpha$-gliadin 33 -mer peptide was reactive with $\alpha$ - $+\beta$-casein (Figures 1 and 2). Therefore, milk, casein and milk-containing products such as milk chocolate should be thought of as containing gluten-like peptides, at least in individuals whose symptoms fail to improve significantly on a GFD. Sec- ond to casein, gliadin antibody reacted considerably with brewer's yeast antigens. We purchased pure brewer's yeast (as per the manufacturer's label) from two different supermarkets. Although an earlier study showed greater than a $50 \%$ homology between certain celiac peptides and Saccharomyces cerevisiae [8], we do not know whether this cross-reaction between $\alpha$-gliadin 33-mer peptide and brewer's yeast antigens is real or if it is associated with impurities and the contamination of commercial products with gluten-containing foods. Oats have been excluded from GFDs largely due to their crosscontamination with gluten-graining grains [21]. There is considerable clinical evidence that some patients with celiac disease have mucosal $\mathrm{T}$ cells that react to the oat prolamine avenin, which can lead to mucosal inflammation. This mucosal T-cell response to avenin may be a reason for villus atrophy in patients that are on a GFD that includes oats $[22,23]$. Our findings presented in Figures 1 and 2 clearly showed that anti-gliadin 33-mer peptide antibody reacted with one cultivar of oats but not with the other. These results confirmed once more that some oat varieties contain avenin, which cross-reacts with wheat, barley, and rye [23].

This also suggests that persons with celiac disease may not consume oats because deamidation or conversion of glutamineto glutamic acid by tissue transglutaminase was involved in the formation of the avenin epitope $[21,24]$. Similar to oats, millet is considered to be a non-gluten- 


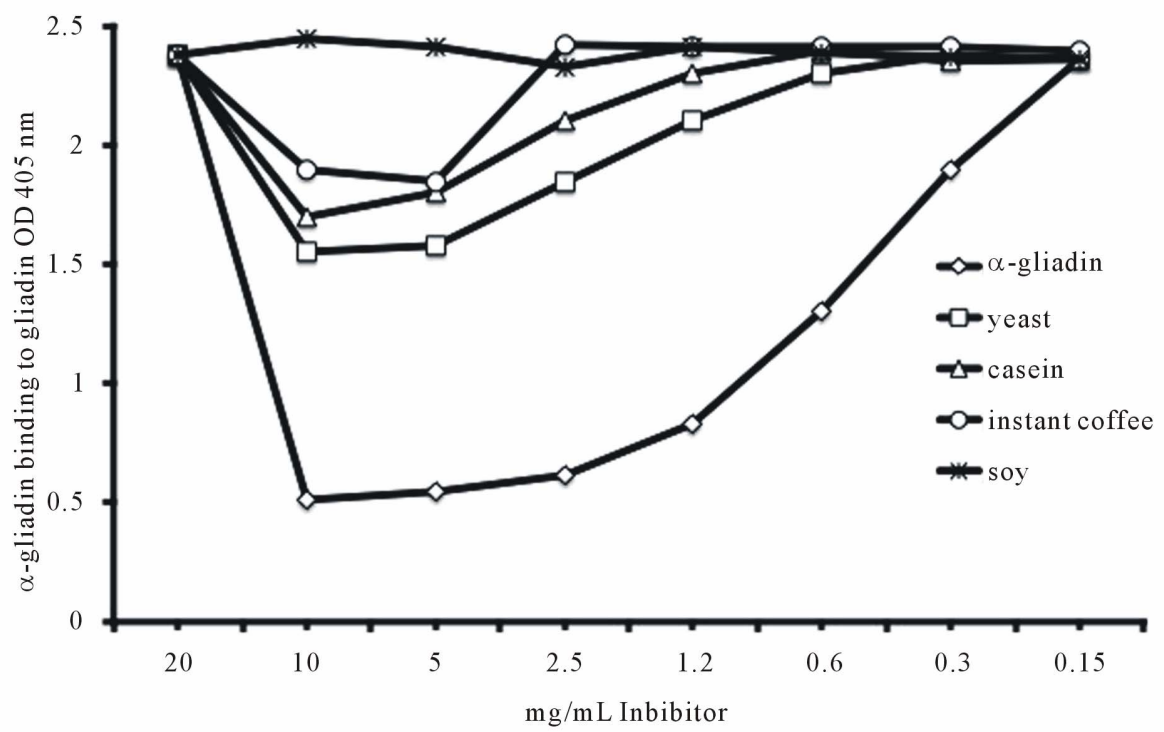

Figure 3. Inhibition of anti- $\alpha$-gliadin 33-mer antibodies by different concentrations of $\diamond \alpha$-gliadin, $\square$ yeast, $\Delta$ casein, oinstant coffee, and $*$ soy.

Table 2. Percent inhibition of affinity-purified $\alpha$-gliadin 33-mer peptide antibody by different antigens.

\begin{tabular}{lccc}
\hline Food antigens & OD & \% Inhibition & $p$ values \\
\hline Control & 2.48 & - & - \\
$\alpha$-gliadin 33-mer peptide & 0.79 & 68 & 0.0006 \\
Brewer's yeast & 1.83 & 26 & 0.0648 \\
$\alpha$ - $+\beta$-casein & 1.95 & 21 & 0.5000 \\
Coffee bean extract & 2.39 & 4 & 0.5000 \\
Instant coffee & 2.1 & 15 & 0.5000 \\
Millet & 1.9 & 23 & 0.0860 \\
Corn & 1.8 & 27 & 0.0572 \\
Rice & 2.08 & 16 & 0.5000 \\
Tissue antigens & OD & $\%$ Inhibition & $p$ values \\
GAD-65 & 1.92 & 23 & 0.0931 \\
Hepatocyte & 1.81 & 27 & 0.0596 \\
Asialoganglioside & 1.57 & 37 & 0.0209 \\
Collagen type IV & 2.39 & 4 & 0.5000 \\
\hline
\end{tabular}

To demonstrate the specificity of anti- $\alpha$-gliadin binding to various food antigens, affinity-purified anti- $\alpha$-gliadin 33 -mer peptide antibody was mixed with a specific antigen ( $\alpha$-gliadin 33-mer peptide) and various non-specific antigens.

containing grain and is often consumed by individuals on a GFD. Based on the results presented in Figures 1, 2, 4 and 5, millet may not be a good substitute for gluten-containing grains for some individuals. This crossreactivity was discussed in an earlier study in which it was shown that amylase inhibitor from barley had a significant homology with millet [25]. We also obtained fresh corn on the cob and various rice grains and observed significant immune reactivity (Figures 1, 2, 4 and 5). In earlier studies, lipid transfer protein, which belongs to the prolamine superfamily, was identified as the major maize allergen with a high cross-reactivity rate with various grains and vegetables [26,27]. A $16 \mathrm{kD}$ rice protein was shown to be a major allergen that cross-reacts with wheat, corn, and Japanese and Italian millet [28].

\subsection{Cross-Reaction between $\alpha$-Gliadin and Coffee Proteins}

Coffee is the most important agricultural commodity in the world [29], and there is much contradictory information spread through the modern media as to whether or not it cross-reacts with gluten. This causes immense confusion among both sufferers of celiac disease and gluten sensitivityand their health providers, who sometimes differ greatly on whether coffee can be safely included in a GFD.

Despite the fact that a considerable amount of protein, ranging from $10 \%-14 \%$ of the dry weight, is found in green and roasted coffee seeds [30-32], there is not enough awareness of the fact that both an immune reaction and an allergy to coffee beans is possible. Coffee bean allergens were identified as early as 1978 [33], and diagnostic methodologies for the identification of coffee allergies have been described [34]. Using these and other methodologies, mucosal and occupational contact dermatitis have been demonstrated in up to $40 \%$ of coffee roaster workers $[35,36]$. On the other hand, a great deal 


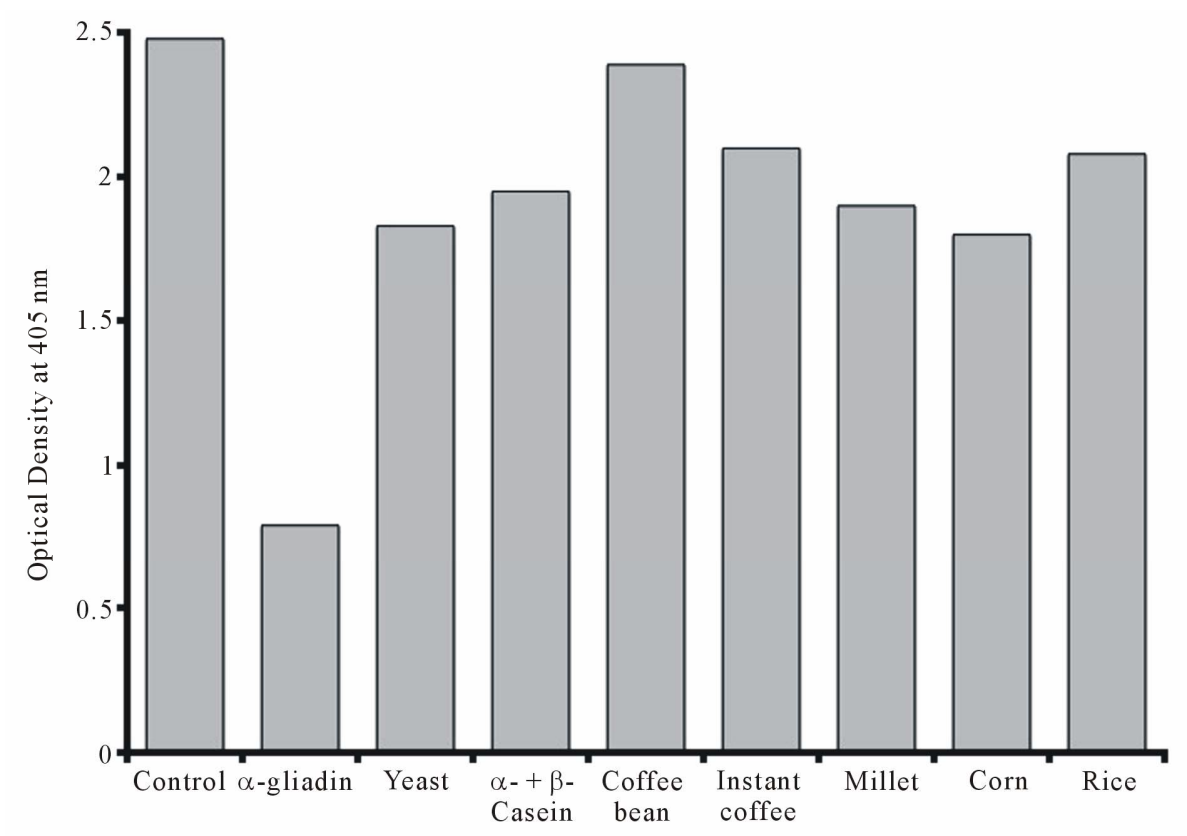

Figure 4. Inhibition of anti- $\alpha$-gliadin 33-mer peptide binding to anti- $\alpha$-gliadin 33-mer peptide by different food antigens.

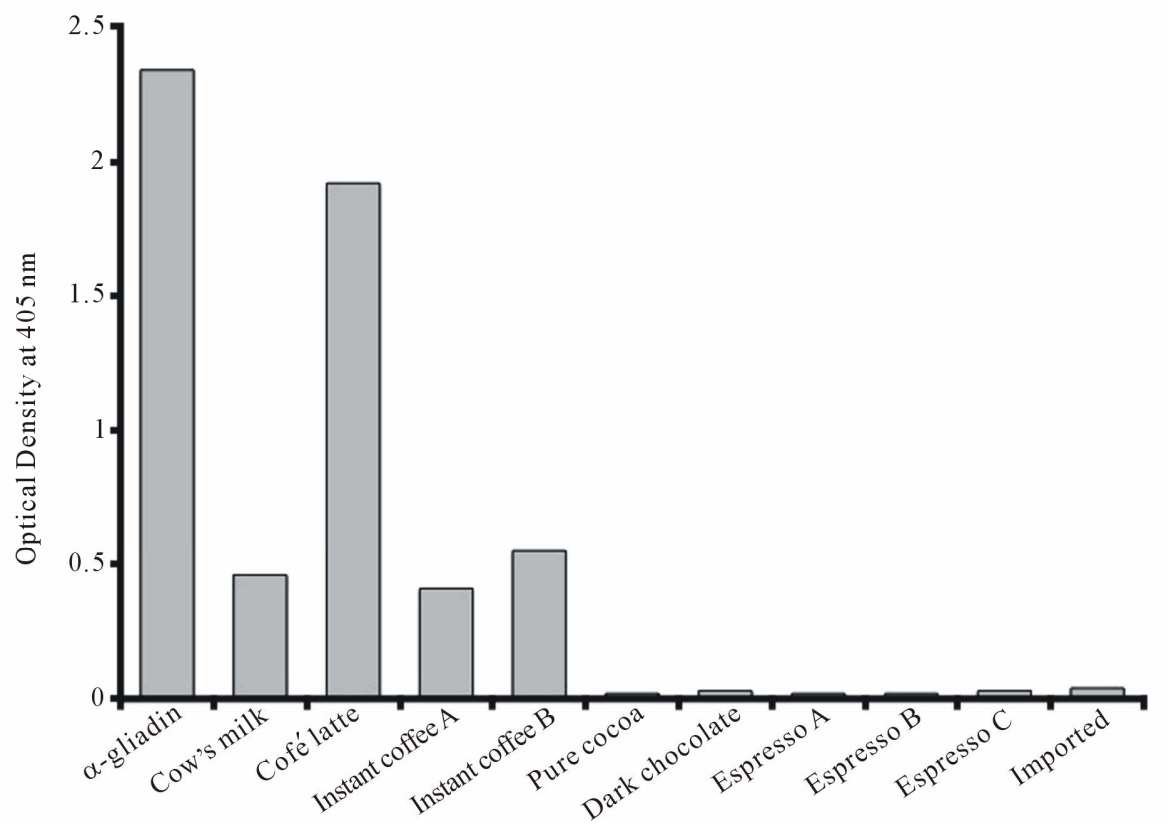

Figure 5. Reaction of affinity-purified $\alpha$-gliadin 33-mer peptide antibodies to gliadin, cow's milk, dark chocolate, cocoa and various coffee preparations.

of publicity was recently generated based on a study conducted by researchers at the National Cancer Institute [37]; this study showed that drinking coffee can lower the death rate from heart disease, respiratory disease, stroke, and diabetes. Because American adults drink 3.2 cups of coffee per day [37], in our own study we placed major emphasis on clarifying whether or not gluten does cross-react with coffee, and we wanted to ensure that drinking various coffee preparations was safe for indi- viduals with gluten sensitivity and celiac disease. For this reason, we measured the reaction of anti- $\alpha$-gliadin 33-mer peptide with various coffee preparations in instant form and from pure coffee beans. The results summarized in Figure 5 show that in comparison to antigliadin binding to gliadin at $100 \%, \alpha$-gliadin antibody reacted with instant café latte at a rate of $82 \%$. Further analysis of these data showed that only $20 \%$ of this immune reaction could be attributed to the milk in the latte 
(see Figure 5, column 2, Cow's milk). We therefore investigated the other materials in latte preparations that were responsible for the other $62 \%$ of immune reactivity. A careful reading of the product labels revealed the declaration that "this product may contain trace amounts of gluten". It became clear that gluten, more than milk, was responsible for the reaction of anti- $\alpha$-gliadin 33-mer peptide with café latte extract. We also found that anti- $\alpha$ gliadin 33-mer peptide reacted up to $23 \%$ with two different preparations of instant coffee that were prepared from selected Arabica coffee beans. The anti- $\alpha$-gliadin 33-mer peptide antibodies reacted neither with fresh espresso purchased from three different coffee houses nor with a mixture of Turkish, Armenian, Greek, and Israeli prepared coffee powder, pure cocoa, or milk-free dark chocolate. These results indicate the following statements: first, instant coffee is contaminated with traces of gluten, which were detected by our sensitive ELISA and inhibition assays; and second, drinking pure coffee but not instant coffee may be safe for individuals with gluten sensitivity and celiac disease as long as these individuals do not have classical allergy to coffee.

\subsection{Inhibition Studies for Demonstration of Cross-Reaction between $\alpha$-Gliadin 33-Mer Peptide and Different Food Antigens}

To demonstrate the specificity of anti- $\alpha$-gliadin binding to various food antigens, affinity-purified anti- $\alpha$-gliadin 33 -mer peptide antibody was mixed with a specific antigen ( $\alpha$-gliadin 33-mer peptide) and various non-specific antigens. The absorption of anti- $\alpha$-gliadin 33-mer peptidewith $\alpha$-gliadin 33-mer peptide resulted in a reduction of OD from 2.48 to 0.79 , or a $68 \%$ inhibition in binding of anti- $\alpha$-gliadin 33-mer peptideto $\alpha$-gliadin 33-mer peptide (Table 2). The absorption with corn, yeast, millet, $\alpha$ $+\beta$-casein, instant coffee and rice antigens inhibited the binding of $\alpha$-gliadin 33 -mer peptide to anti- $\alpha$-gliadin 33 -mer peptide by $27 \%, 26 \%, 23 \%, 21 \%, 16 \%$, and $15 \%$, respectively. In comparison, coffee bean extract resulted in a non-specific inhibition of $4 \%$, which was within the background variation of the ELISA assay (Table 2).

To further demonstrate the specificity of the antigen-antibody reactions, affinity-purified $\alpha$-gliadin 33mer peptide antibody was mixed with varying amounts of food antigens $(10 \mathrm{mg} / \mathrm{mL}-150 \mu \mathrm{g} / \mathrm{mL})$ in the liquid phase and was applied to microtiter plate wells coated with $\alpha$-gliadin peptide. $\alpha$-gliadin at $10 \mathrm{mg} / \mathrm{mL}$ resulted in a $79 \%$ inhibition of antibody binding to $\alpha$-gliadin 33 -mer peptide-coated plates. This inhibition by $\alpha$-gliadin $33-$ mer peptide was reversed by lowering the concentration of the antigens in the liquid phase to $150 \mu \mathrm{g} / \mathrm{mL}$. A similar pattern of inhibition but at a much lower rate was observed when high concentrations $(2.5-10 \mathrm{mg} / \mathrm{mL})$ of yeast, casein, and instant coffee were added to the liquid phase. Similarly high concentrations of up to $10 \mathrm{mg} / \mathrm{mL}$ of soy did not cause any inhibition of anti- $\alpha$-gliadin 33mer peptide binding to the gliadin-coated plates (Figure 3).

\subsection{Cross-Reaction between $\alpha$-Gliadin and Different Tissue Antigens}

During the past decade, it has been well established that $\mathrm{CD}$ is associated with various extraintestinal autoimmunities that involve the thyroid, joints, heart, skin, pancreas, bone, liver, reproductive organs, and the nervous system [38-47]. Although the exact mechanisms for the induction of these autoimmunities are not definitively known, there is a growing body of evidence indicating that these diseases may result from molecular mimicry between gliadin or transglutaminase and various tissue antigens, including nervous system proteins $[8,41-43,48]$. Interestingly, the celiac peptide VVKVGGSSSLGW shares more than $30 \%$ homology with the transglutaminase peptide 476-487 (RIRVGQSMNMGS) [8]. In earlier studies, it was established that antibodies against transglutaminase generated in the intestine can bind to extraintestinal tissues such as those of the liver, pancreas, lymph nodes, muscle, heart and brain [7,44-46,48-51]. These studies demonstrated that the circulating antibodies present in celiac disease interact with ubiquitous transglutaminases in various tissues, which may induce the formation of protein aggregates that may trigger inflammation [48]. In the present study, affinity-purified rabbit anti- $\alpha$-gliadin 33-mer peptide were reacted with gliadin and different tissue antigens. The degree of antibody binding to different antigens and peptides was measured. The addition of anti- $\alpha$-gliadin 33-mer peptide to $\alpha$-gliadin 33-mer peptide resulted in an OD of 2.74 , which was considered as $100 \%$ binding (Figure 6). However, in comparison to anti- $\alpha$-gliadin binding to gliadin peptide, binding of this antibody to various tissue antigens or peptides resulted in the most significant OD for asialoganglioside (0.95), hepatocyte (0.82), GAD-65 (0.77), adrenal 21-hydroxylase (adrenal) (0.62), myelin basic protein (MBP) $(0.55)$, cerebellar $(0.05)$, osteocyte $(0.49)$, synapsin and myocardial peptide $(0.45)$, ovarian peptide (0.44), and thyroid peroxidase (0.41). The ODs for testes peptide, islet cell antigen, parietal and intrinsic factor were between 0.34 and 0.39 . The anti- $\alpha$-gliadin reaction against neutrophil cytoplasmic antigen, tropomyosin, thyroglobulin, $\alpha$-myosin, phospholipid, platelet glycoprotein, fibulin, collagen, arthritic peptide, insulin, and $\alpha$ - $+\beta$-tubulin resulted in non-significant ODs of less than 0.2 (Figure 6). The affinity-purified serum from a pre-immunized rabbit was also applied to $\alpha$-gliadin 


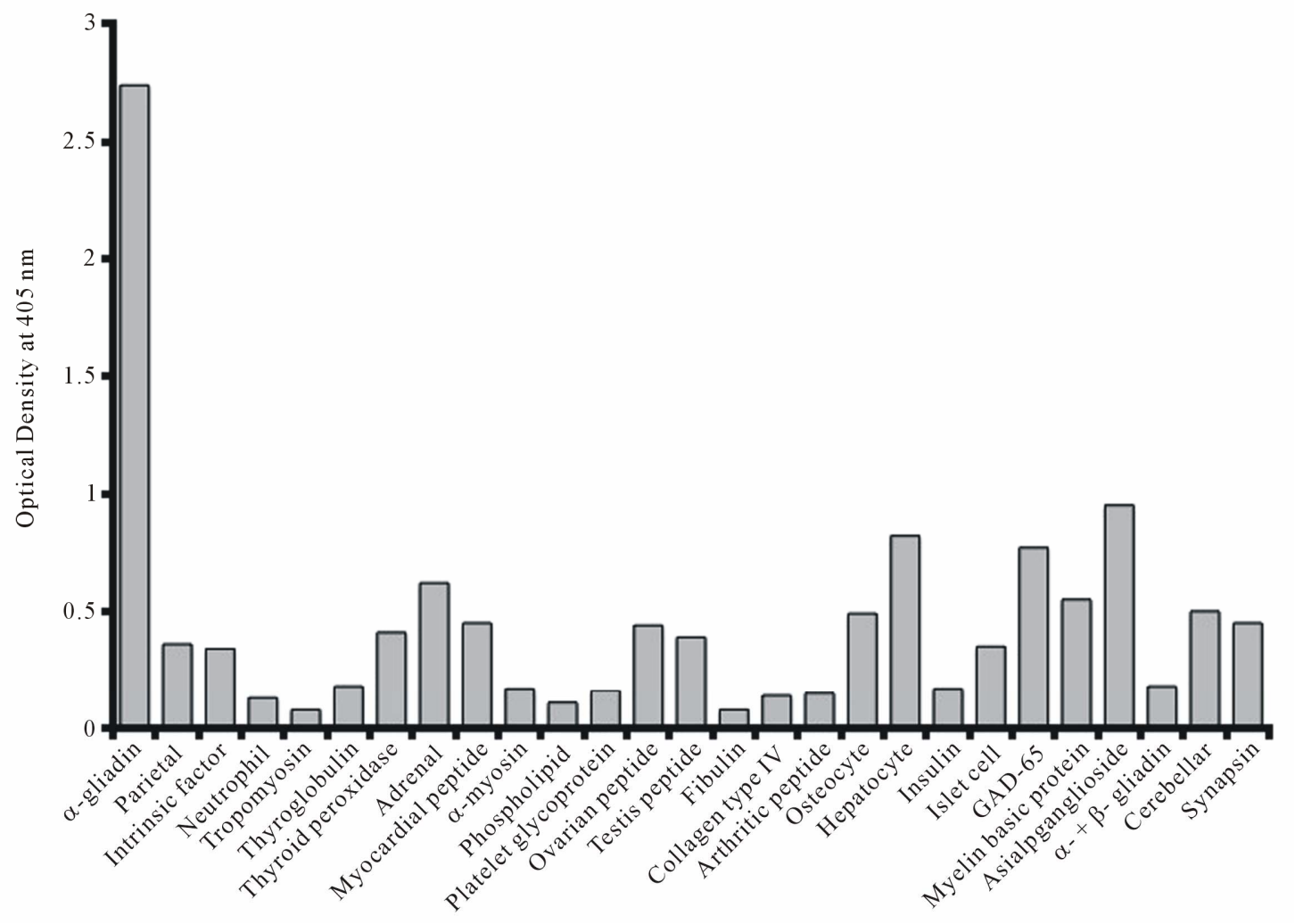

Figure 6. Reaction of anti- $\alpha$-gliadin 33-mer peptide antibodies to gliadin and various tissue antigens. Adrenal $=$ Adrenal 21-hydroxylase. Hepatocyte $=$ Hepatocyte cytochrome P-450.

33-mer peptide and all tissue antigens, which resulted in ODs of less than 0.15 (data not shown).

To demonstrate the specificity of these immune reactions, anti- $\alpha$-gliadin 33 -mer peptide binding to $\alpha$-gliadin 33 -mer peptide was measured in the presence of HSA or cross-reactive tissue antigens such as GAD-65, hepatocyte, asialoganglioside, and collagen. The results summarized in Table 2 and Figure 7 show that only the tissues GAD-65, hepatocyte and asialoganglioside inhibited this antigen-antibody reaction at $23 \%, 27 \%$ and $37 \%$, respectively. In comparison, collagentype IV caused a non-significant inhibition of anti- $\alpha$-gliadin 33 -mer peptide binding to $\alpha$-gliadin 33-mer peptide (Table 2).

\subsection{Demonstration of Cross-Reactivity Using Dot-Blot}

Affinity-purified polyclonal and monoclonal antibodies prepared against $\alpha$-gliadin 33-merpeptide were examined for their binding capacity to $\alpha$-gliadin 33-mer peptide and a select number of food and tissue antigens. As shown in Figures 8 and 9, strong specific staining was observed with gliadin; staining was observed to a lesser degree with instant coffee, corn, yeast, $\alpha-+\beta$-casein, millet, rice, milk, milk butyrophilin and oats. No staining was observed with casomorphin, egg, pure coffee bean, cocoa and sorghum. The reaction of anti- $\alpha$-gliadin 33-mer peptide was significant when it was applied to GAD-65, hepatocyte, asialoganglioside, synapsin, MBP and cerebellar, but not with collagen type IV, tropomyosin and HSA (Figures 8 and 9).

The demonstration of cross-reactivity between $\alpha$-gliadin 33-mer peptide antibodies with various tissue antigens is important to show that celiac patients have an increased risk for various autoimmunities, and a gluten-free diet may not be sufficient to prevent the progression of autoimmune processes. Indeed, in a very recent study, a one-year follow-up revealed that the gluten-free diet was not enough to reverse autoimmune atrophic thyroiditis, which was demonstrated by ultrasound findings, thyroid function tests or thyroid autoantibodies [52]. This lack of improvement in the autoimmune process may be associated with the consumption of foods that were contaminated with trace amounts of gluten during manufacturing, as was shown in this study by comparing instant coffee with coffee prepared from coffee beans. Additionally, as indicated in an earlier study [53], many countries traditionally allow foods contaminated with up to $0.3 \%$ of proteins from glutein-containing grains to be labeled as "gluten-free" [53]. Allowing up to $0.3 \%$ of proteins from glutein-containing grains in other foods is not immunologically rational because gliadin-specific 


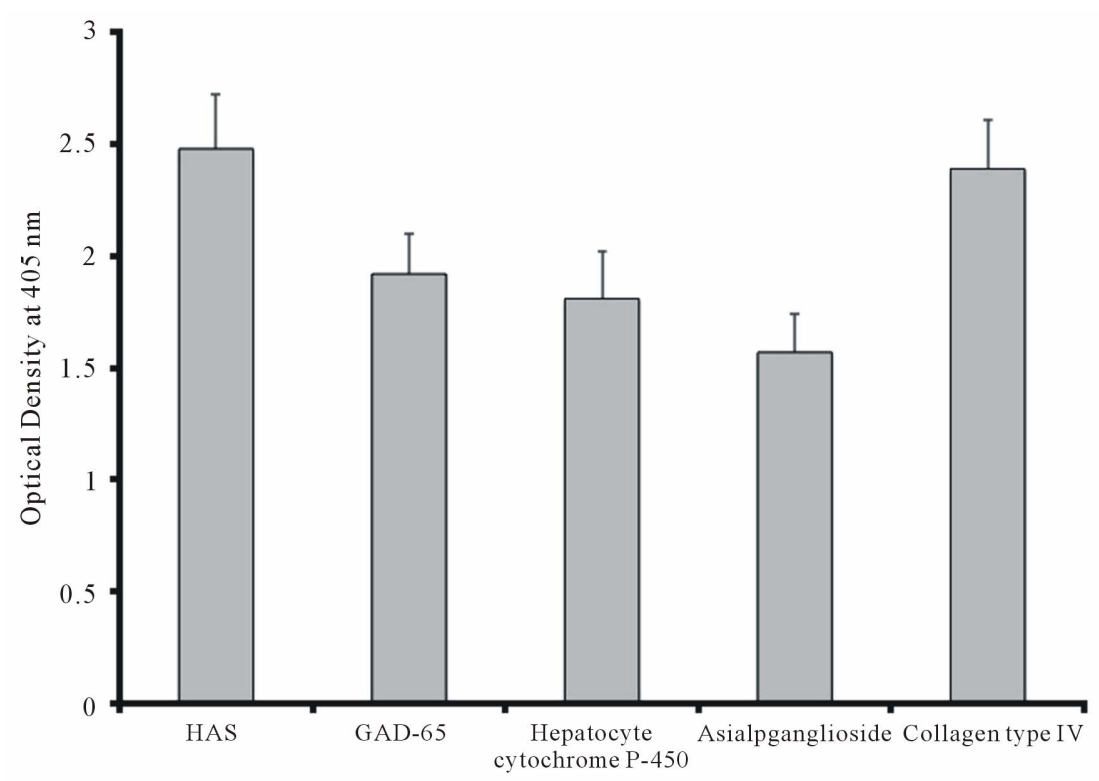

Figure 7. Inhibition of $\alpha$-gliadin 33-mer peptide antibodies binding to $\alpha$-gliadin 33-mer peptideby various tissue antigens.

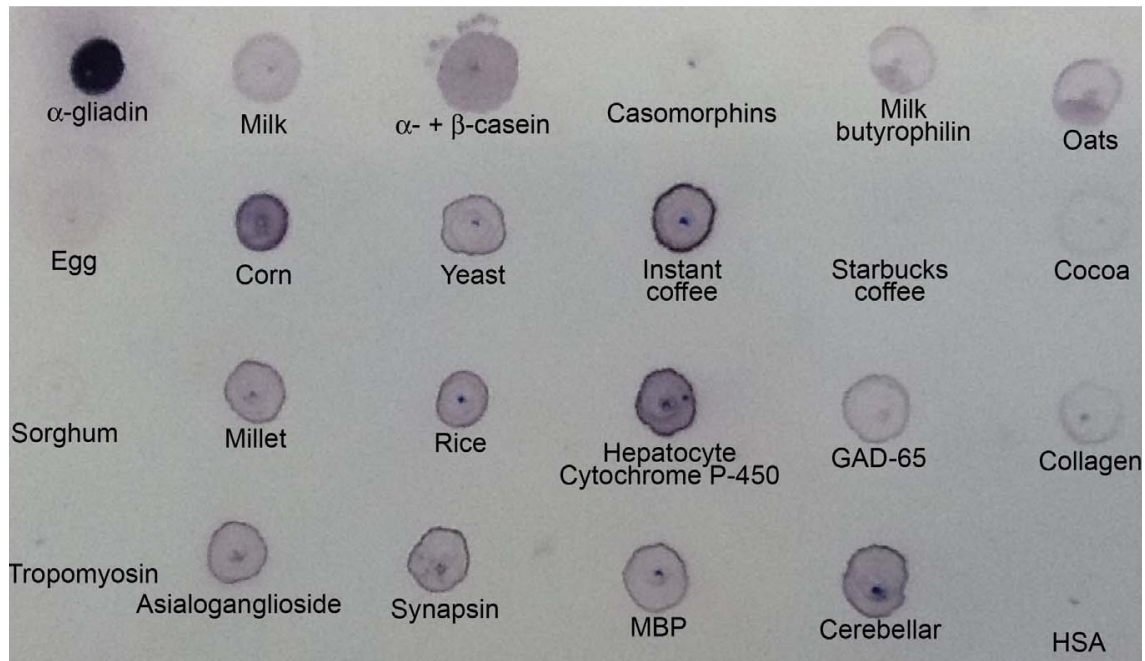

Figure 8. Reaction of polyclonal anti- $\alpha$-gliadin 33-mer to $\alpha$-gliadin 33-mer and various tissue and food antigens by dot-blot.

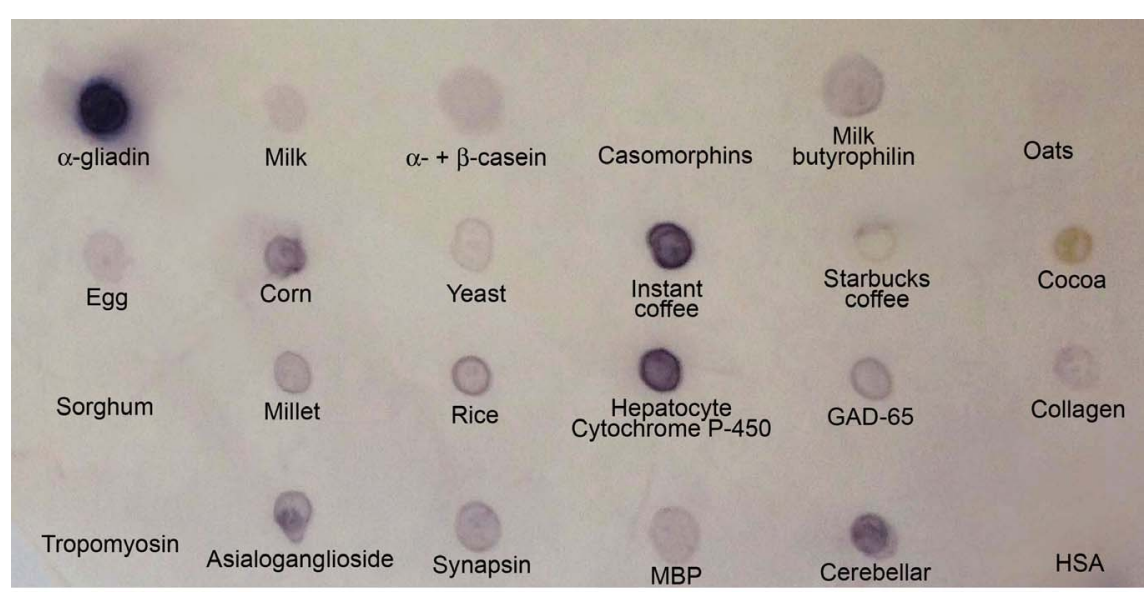

Figure 9. Reaction of monoclonal anti- $\alpha$-gliadin 33-mer to $\alpha$-gliadin 33-mer and various tissue and food antigens by dot-blot. 
memory $\mathrm{T}$ cells may react to micrograms of proteins and produce proinflammatory cytokines that can contribute to gastrointestinal and extra-gastrointestinal symptoms. Therefore, patients on a gluten-free diet should adhere to a zero tolerance policy. This requires not only abstinence from gluten-free foods but also reading labels carefully, checking for the country of manufacturing origin, and statements such as "produced in a factory that also processes wheat, gluten and dairy". It is advisable to do clinical follow-ups of non-celiac gluten-sensitive and celiac disease patients who consume cross-reactive foods, focusing particularly on their association with autoimmune reactivity.

\section{Conclusions}

If a subgroup of patients on a gluten-free diet does not show improvement in their GI or other symptoms, attention should be given to dairy and other cross-reactive foods, such as yeast, corn, oats, millet and rice, as shown in the present study. If after adherence to a strict gluten-free diet and the elimination of cross-reactive foods symptoms still persist, further investigation for other food intolerances should follow.

In the absence of the proper dietary elimination of gluten, the present study supports the hypothesis that if the high prevalence of antibodies against dietary proteins and peptides and their cross-reaction with various tissue antigens are not taken seriously, and if proper measures are not implemented, the result may be the development of autoimmunity in the future.

\section{Acknowledgements}

We would like to thank Joel Bautista for his substantial contributions towards the preparation of this article, including the figures and tables.

\section{REFERENCES}

[1] D. H. Dewar and P. J.Ciclitira, "Clinical Features and Diagnosis of Coeliac Disease," Gastoenterology, Vol. 128 , No. 4, 2005, pp. S19-S24. doi:10.1053/j.gastro.2005.02.010

[2] V. Verhasselt, "Oral Tolerance in Neonates: From Basics to Potential Prevention of Allergic Disease," Mucosal Immunology, Vol. 3, No. 4, 2010, pp. 326-333. doi: $10.1038 / \mathrm{mi} .2010 .25$

[3] A. Vojdani, "The Characterization of the Repertoire of Wheat Antigens and Peptides Involved in the Humoral Immune Responses in Patients with Gluten Sensitivity and Crohn's Disease," ISRN Allergy, Vol. 2011, 2011, Article ID: 950104.

[4] M. Hadjivassiliou, C. A. Williamson and N. Woodroofe, "The Immunology of Gluten Sensitivity: Beyond the Gut," Trends in Immunology, Vol. 25, No. 11, 2004, pp.

\section{8-582. doi:10.1016/j.it.2004.08.011}

[5] P. H. R. Green and C. Cellier, "Coeliac Disease," New England Journal of Medicine, Vol. 357, No. 17, 2007, pp. 1731-1743. doi:10.1056/NEJMra071600

[6] A. Lanzini, F. Lanzarotto, V. Villanacci, A. Mora, S. Bertolazzi, et al., "Complete Recovery of Intestinal Mucosa Occurs Very Rarely in Adult Coeliac Patients Despite Adherence to Gluten-Free Diet," Alimentary Pharmacologyand Therapeutics, Vol. 29, No. 12, 2009, pp. 1299-1308. doi:10.1111/j.1365-2036.2009.03992.x

[7] M. Hadjivassiliou, A. K. Chattopadhyay, G. A. B. Davies-Jones, A. Gibson, R. A. Grünewald, et al., "Neuromuscular Disorder as a Presenting Feature of Coeliac Disease," Journal of Neurology, Neurosurgery and Psychiatry with Practical Neurology, Vol. 63, No. 6, 1997, pp. 770-775. doi:10.1136/jnnp.63.6.770

[8] G. Zanoni, R. Navone, C. Lunardi, G. Tridente, C. Bason, et al., "In Coeliac Disease, a Subset of Autoantibodies against Transglutaminase Binds Toll-Like Receptor 4 and Induces Activation of Monocytes," Public Library of Science Medicine, Vol. 3, No. 9, 2006, pp. 1637-1652.

[9] A. G. Pockley, "Heat Shock Proteins as Regulators of the Immune Response," Lancet, Vol. 362, No. 9382, 2003, pp. 469-476. doi:10.1016/S0140-6736(03)14075-5

[10] M. Amagai, "Desmoglein as a Target in Autoimmunity and Infection," Journal of the American Academy of Dermatology, Vol. 48, No. 2, 2003, pp. 244-252. doi: $10.1067 / \mathrm{mjd} .2003 .7$

[11] J. Laporte, F. Beder, A. Bolino and J. L. Mandel, "Myotubularins, a Large Disease-Associated Family of Cooperating Catalytically Active and Inactive Phosphoinositides Phosphatases," Human Molecular Genetics, Vol. 12, No. R2, 2003, pp. R285-R292. doi:10.1093/hmg/ddg273

[12] S. E. Blutt, S. E. Crawford, K. L. Warfield, D. E. Lewis, M. K. Estes, et al., "The VP7 Outer Capsid Protein of Rotavirus Induces Polyclonal B-Cell Activation," Journal of Virology, Vol. 78, No. 13, 2004, pp. 6974-6981. doi:10.1128/JVI.78.13.6974-6981.2004

[13] G. Kristjansson, P. Venge and R. Hallgren, "Mucosal Reactivity to Cow's Milk Protein in Coeliac Disease," Clinicaland Experimental Immunology, Vol. 147, No. 3, 2007, pp. 449-455. doi:10.1111/j.1365-2249.2007.03298.x

[14] A. Fasano, "Zonulin and Its Regulation of Intestinal Barrier Function: The Biological Door to Inflammation, Autoimmunity, and Cancer," Physiological Reviews, Vol. 91, No. 1, 2011, pp. 151-175. doi:10.1152/physrev.00003.2008

[15] A. Vojdani, "Detection of $\operatorname{IgE}, \operatorname{IgG}, \operatorname{IgA}$ and IgM Antibodies against Raw and Processed Food Antigens," Nutrition and Metabolism, Vol. 6, 2009, p. 22. doi:10.1186/1743-7075-6-22

[16] S. Husby, S. Koletzko, I. R. Korponay-Szabo, et al., "European Society for Pediatric Gastroenterology Hepatology and Nutrition Guidelines for the Diagnosis of Coeliac Disease," Journal of Pediatric Gastroenterology and Nutrition, Vol. 54, No. 1, 2012, pp. 136-160. doi:10.1097/MPG.0b013e31821a23d0 
[17] C. Mitea, Y. Kooy-Winkelaar, P. V. Veelen, A. de Ru, J. W. Drijfhout, et al., "Fine Specificity of Monoclonal Antibodies against Coeliac Disease-Including Peptides in the Gluteome," The American Journal of Clinical Nutrition, Vol. 88, No. 4, 2008, pp. 1057-1066.

[18] M. Darewicz, J. Dziuba and P. Minkiewicz, "Computational Characterization and Identification of Peptides for In Silico Detection of Potentially Coeliac-Toxic Proteins," Food Science and Technology International, Vol. 13, No. 2, 2007, pp. 125-133. doi:10.1177/1082013207077954

[19] C. Berti, C. Trovat, M. T. Bardella and F. Forlani, "IgA Anti-Gliadin Antibody Immunoreactivity to Food Proteins," Food and Agricultural Immunology, Vol. 15, No. 3-4, 2003, pp. 217-223. doi:10.1080/09540100400003204

[20] F. Cabrera-Chavez and A. M. Calderon de la Barca, "Bovine Milk Intolerance in Celiac Disease Is Related to IgA Reactivity to and Casein," Nutrition, Vol. 25, No. 6, 2009, pp. 715-716. doi:10.1016/j.nut.2009.01.006

[21] T. Thompson, "Gluten Contamination of Commercial Oat Products in the United States," New England Journal of Medicine, Vol. 351, No. 19, 2004, pp. 2021-2022. doi:10.1056/NEJM200411043511924

[22] H. Arentz-Hansen, B. Fleckenstin, O. Mulberg, H. Scott, F. Koning, et al., "The Molecular Basis for Oats Intolerance in Patients with Celiac Disease," Public Library of Science Medicine, Vol. 1, No. 1, 2004, p. e1.

[23] I. Comino, A. Real, L. de Lorenzo, H. Cornell, M. A. Lopez-Casado, et al., "Diversity in Oat Potential Immunogenicity: Basis for the Selection of Oat Varieties with No Toxicity in Coeliac Disease," Gut, Vol. 60, No. 7, 2011, pp. 915-922. doi:10.1136/gut.2010.225268

[24] U. Srinivasan, E. Jones, J. Carolan and C. Feighery, "Immunohistochemical Analysis of Coeliac Mucosa Following Ingestion of Oats," Clinincal and Experimental Immunology, Vol. 144, No. 2, 2006, pp. 197-203. doi:10.1111/j.1365-2249.2006.03052.x

[25] W. R. Bernard and C. R. Sommerville, "Coidentity of Putative Amylase Inhibitors from Barley and Finger Millet with Phospholipid Transfer Protein Inferred from Amino Acid Sequence Homology," Archives of Biochemisgtry and Biophysics, Vol. 269, No. 2, 1989, pp. 695-697. doi:10.1016/0003-9861(89)90154-9

[26] E. A. Pastorello, C. Compei, V. Pravettoni, L. Farioli, A. M. Calamari, et al., "Lipid Transfer Protein Is the Major Maize Allergen Maintaining IgE-Binding Activity after Cooking at $100^{\circ} \mathrm{C}$, as Demonstrated in Anaphylactic Patients and Patients with Positive Double-Blind, Placebo-Controlled Food Challenge Results," Journal of Allergy and Clinical Immunology, Vol. 112, No. 4, 2003, pp. 775-783. doi:10.1016/S0091-6749(03)01942-0

[27] E. A. Pastorello, L. Farioli, V. Pravettoni, C. Ortolani, D. Fortunato, et al., "Identification of Grape and Wine Allergens as an Endichitinase 4, a Lipid-Transfer Protein, and a Thaumatin," Journal of Allergy and Clinical Immunology, Vol. 111, No. 2, 2003, pp. 350-359. doi:10.1067/mai.2003.35

[28] A. Urisu, K. Yamada, S. Masuda, H. Komada, E. Wada, et al., "16-Kilodalton Rice Protein Is One of the Major Allergens in Rice Grain Extract and Responsible for Cross-Allergenicity between Cereal Grains in the Poaceae Family," International Archives of Allergy and Immunology, Vol. 96, No. 3, 1991, pp. 244-252. doi: $10.1159 / 000235502$

[29] J. M. Mondego, R. O. Vidal, M. F. Carazzolle, E. K. Tokuda, L. P. Parizzi, et al., "An EST-Based Analysis Identifies New Genes and Reveals Distinctive Gene Expression Features of Coffeaarabica and Coffeacanephora," Bio Med Central Plant Biology, Vol. 11, 2011, p. 30. doi:10.1186/1471-2229-11-30

[30] H. V. Amorim and R. V. Josephson, "Water Soluble Protein and Nonprotein Components of Brazilian Green Coffee Beans," Journal of Food Science, Vol. 40, No. 6, 1975, pp. 1179-1185.

doi:10.1111/j.1365-2621.1975.tb01047.x

[31] H. Bade and H. Stegemann, "Protein Patterns of Coffee Beans. Characterization by One- and Two-Dimensional Electrophoresis," Journalof Agronomyand Crop Science, Zeitschrift fur Acker und Pflanzenbau, Vol. 151, No. 2, 1982, pp. 89-98.

[32] M. Lepelley, V. Mahesh, J. McCarthy, M. Rigoreau, D. Crouzillat, et al., "Characterization, High-Resolution Mapping and Differential Expression of Three Homologous PAL Genes in Coffea canephora Pierre (Rubiaceae)," Planta, Vol. 236, No. 1, 2012, pp. 313-326. doi:10.1007/s00425-012-1613-2

[33] S. B. Lehrer, R. M. Karr and J. E. Salvaggio, "Extraction and Analysis of Coffee Bean Allergens," Clinical Allergy, Vol. 8, No. 3, 1978, pp. 217-226.

[34] K. Osterman, S. G. Johansson and O. Zetterstrom, "Diagnostic Tests in Allergy to Green Coffee," Allergy, Vol. 40, No. 5, 1985, pp. 336-343.

[35] T. S.Sonnex, R. P. P. Dawber and T. J. Ryan, "Mucosal Contact Dermatitis Due to Instant Coffee," Contact Dermatitis, Vol. 7, No. 6, 1981, pp. 298-300.

[36] R. Treudler, B. Tebbe and C. E. Orfanos, "Coexistence of Type I and Type IV Sensitization in Occupational Coffee Allergy," Contact Dermatitis, Vol. 36, No. 2, 1997, p. 109.

[37] N. D. Freedman, Y. Park, C. C. Abnet, A. R. Hollenbeck and R. Sinha, "Association of Coffee Drinking with Total and Cause-Specific Mortality," New England Journal of Medicine, Vol. 366, No. 20, 2012, pp. 1891-1904.

[38] M. Hvatum, L. Kanerud, R. Hällgren and P. Brandtzaeg. "The Gut-Joint Axis: Cross Reactive Food Antibodies in Rheumatoid Arthritis," Gut, Vol. 55, No. 9, 2006, pp. 1240-1247.

[39] E. Sugai, A. Cherñavsky, S. Pedreira, E. Smecuol, H, Vasquez, et al., "Bone-Specific Antibodies in Sera from Patients with Celiac Disease: Characterization and Implications in Osteoporosis," Journal of Clinical Immunology, Vol. 22, No. 6, 2002, pp. 353-362.

[40] A. Frustaci, L. Cuoco, C.Chimenti, M. Pieroni, G. Fioravanti, et al., "Celiac Disease Associated with Autoimmune Myocarditis," Circulation, Vol. 105, No. 22, 2002, pp. 2611-2618. 
[41] M. Hadjivassiliou, M. Maki, D. S.Sanders, et al, "Autoantibody Targeting of Brain and Intestinal Transglutaminase in Gluten Ataxia," Neurology, Vol. 66, No. 3, 2006, pp. 373-377. doi:10.1212/01.wnl.0000196480.55601.3a

[42] A. Vojdani, T. O’Bryan, J. A. Green, J. McCandless, K. N. Woeller, et al., "Immune Response to Dietary Proteins, Gliadin and Cerebellar Peptides in Children with Autism," Nutritional Neuroscience, Vol. 7, No. 3, 2004, pp. 151-161. doi:10.1080/10284150400004155

[43] A. Alaedini, H. Okamoto, C. Briani, K. Wollenberg, H. A. Shill, et al., "Immune Cross-Reactivity in Coeliac Disease: Anti-Gliadin Antibodies Bind to Neuronal Synapsin I," Journal of Immunology, Vol. 178, No. 10, 2007, pp. 6590-6595.

[44] C. L. Ching, M. K. Jones and J. G. C. Kingham, "Celiac Disease and Autoimmune Thyroid Disease," Clinical Medicine and Research, Vol. 5, No. 3, 2007, pp. 184-192.

[45] S. Bödvarsson, I. Jónsdóttir, J. Freysdóttir, J. N. Leonard, L. Fry, et al., "Dermatitis Herpetiformis-An Autoimmune Disease Due to Cross-Reaction between Dietary Glutenin and Dermal Elastin?" Scandinavian Journal of Immunology, Vol. 38, No. 6, 1993, pp. 546-550.

[46] D. B. Shor, O. Barzillai, M. Ram, D. Izhaky, B. S. Porat-Katz, et al., "Gluten Sensitivity in Multiple Sclerosis: Experimental Myth or Clinical Truth?" Annals of the New York Academy of Sciences, Vol. 1173, 2009, pp. 343-349.

[47] C. O'Leary, C. H. Walsh, P. Wieneke, P. O’Regan, B. Buckley, et al., "Coeliac Disease and Autoimmune Addison's Disease: A Clinical Pitfall," Quarterly Journal of Medicine, Vol. 95, No. 2, 2002, pp. 79-82.

[48] A. J. Naiyer, J. Shah, L. Hernandez, S. Y. Kim, E. J. Ciaccio, et al., "Tissue Transglutaminase Antibodies in
Individuals with Coeliac Disease Bind to Thyroid Follicles and Extra Cellular Matrix and May Contribute to Thyroid Dysfunction,” Thyroid, Vol. 18, No. 11, 2008, pp. 1171-1178.

[49] C. Sategna-Guidetti, E. Franco, S. Martini and M. Bobbio, "Binding by Serum IgA Antibodies from Patients with Coeliac Disease to Monkey Heart Tissue," Scandinavian Journal of Gastroenterology, Vol. 39, No. 6, 2004, pp. 540-543.

[50] E. V. Marietta, M. J. Camilleri, L. A. Castro, P. K. Krause, M. R. Pittelkow, et al., "Transglutaminase Autoantibodies in Dermatitis Herpetiformis and Coeliac Sprue," Journal of Investigative Dermatology, Vol. 128, No. 2, 2008, pp. 332-335.

[51] V. Toscano, F. G. Conti, E. Anastasi, et al., "Importance of Gluten in the Induction of Endocrine Autoantibodies and Organ Dysfunction in Adolescent Coeliac Patients," American Journal of Gastroenterology, Vol. 95, No. 7, 2000, pp. 1742-1748. doi:10.1111/j.1572-0241.2000.02187.x

[52] S. Metso, H. Hyytiä-Ilmonen, K. Kaukinen, H. Huhtala, P. Jaatinen, et al., "Gluten-Free Diet and Autoimmune Thyroiditis in Patients with Coeliac Disease. A Prospective Controlled Study," Scandinavian Journal of Gastroenterology, Vol. 47, No. 1, 2012, pp. 43-48. doi:10.3109/00365521.2011.639084

[53] K. B. Faulkner-Hogg, W. S. Selby and R. H. Loblay, "Dietary Analysis in Symptomatic Patients with Coeliac Disease on a Gluten-Free Diet: The Role of Trace Amounts of Gluten and Non-Gluten Food Intolerance," Scandinavian Journal of Gastroenterology, Vol. 34, No. 8, 1999, pp. 784-789. doi:10.1080/003655299750025714 